\title{
Entrepreneurship in a Globalised Economy
}

\author{
M.Pramila Devi, Dr.S.Ramachandran, \\ Bharath University, Chennai. \\ Asst.Prof, Sir.Theagaraya College, Chennai \\ Director, Department Of Management Studies, Bharath University, Chennai
}

\begin{abstract}
Globalization, as a concept, refers both to the "Shrinking" of the world and our increased consciousness of the world as a whole. It is a term used to describe the changes in societies and the world economy that have resulted from dramatically increased cross-broader trade, investment and cultural exchange. The affects of globalization have been felt in every nation, region and culture as it has produced a growing interdependence of people with regard to political systems, social influence, economics and cultural exchanges.

India's approach to the promotion of entrepreneurial firms is unique, and to some extent, overwhelming. The country has a dedicated ministry for small scale industries at the federal level supported by several agencies at federal and state levels. Besides, numerous commercial banks, regional rural banks, urban and cooperative credit lending institutions participate in funding the micro, small, and medium enterprises. Such an effort, though seemingly superfluous, is the dire need for a country to enhance the competitiveness of entrepreneurial firms in order to unite them under an organized structure and integrate their operations into that of major global firms. Three national-level Entrepreneurship Development Institutes are engaged in skill development. This paper offers a critique of the present policy with regards to the SMEs with a prospective outlook into their future.
\end{abstract}

\section{Introduction}

Globalization, as a concept, refers both to the "Shrinking" of the world and our increased consciousness of the world as a whole. It is a term used to describe the changes in societies and the world economy that have resulted from dramatically increased cross-broader trade, investment and cultural exchange. The affects of globalization have been felt in every nation, region and culture as it has produced a growing interdependence of people with regard to political systems, social influence, economics and cultural exchanges.

Micro, Small and Medium Enterprises (MSMEs) plays a significant role in the economic growth of the country owing to their contribution to production, exports and employment. The sector contributes 8 per cent to the country's GDP, 45 per cent to the manufacture output and 40 per cent to the country exports. It provides employment to 60 million people through 28.5 million enterprises.

In this paper, the primary interest focuses on the increasing economic integration and interdependence of countries that has resulted from globalization and entrepreneurial opportunities that result. Globalization has increased the flow of goods, services, people, real capital and money across national borders, resulting in a more integrated and interdependent world economy. The entrepreneurs contributing a lot in globalising economy by promoting activities in competitive market.

\section{Entrepreneurship in a Global Economy}

While most countries place most entrepreneurial firms in the category of small and medium-sized enterprises (SMEs), India refers to such firms as „Micro, Small and Medium Enterprises. (MSME). After a longstanding demand from various entrepreneurs, small industry associations and related stakeholders for a single comprehensive legislation, the "Micro, Small and Medium Enterprises Development (MSMED) Act, 2006" was enacted. This is the first Act that provides for a precise definition of these enterprises besides paving way for a statutory National Board exclusively for them helps implement promotion schemes and addresses the development and enhancement of firms competitiveness.

The Micro, Small and Medium Enterprises Development (MSMED) Act was notified in 2006 to address policy issues affecting MSME as well as the coverage and investment ceiling of the sector. The Act seeks to facilitate the development of these enterprises as also enhance their competitiveness. It provides the first - ever legal frame work for recognition of the concept of "enterprise" which comprises both manufacturing and service entities. It defines medium enterprises for the first time and seeks to integrate the three tiers of these enterprises, namely, Micro, Small and Medium Enterprise.

Micro, Small \& Medium Enterprises (MSMEs) are defined in the act as 


\subsection{Micro, Small \& Medium Enterprises Development(MSMED) Act 2006}

The Micro, Small and Medium Enterprises Development (MSMED) Act 2006 facilitate the development of the enterprises and enhance their competitiveness. The act provides legal framework for "enterprise" which includes the manufacturing and service entities.

In accordance with the provisions of Micro, Small \& Medium Enterprises Development (MSMED) Act 2006, the Micro, Small \& Medium Enterprises (MSME) are classified into manufacturing enterprises and service enterprises:

(a) Manufacturing Enterprises: The enterprises engaged in the manufacture or production of goods. The manufacturing Enterprises are defined in terms of investment in Plant \& Machinery.

(b) Service Enterprises: The enterprises engaged in providing or rendering of services and are defined in terms of investment in equipment.

The investment limits of the enterprises are shown in the diagram given below:

Diagram 1: Classification of MSME's

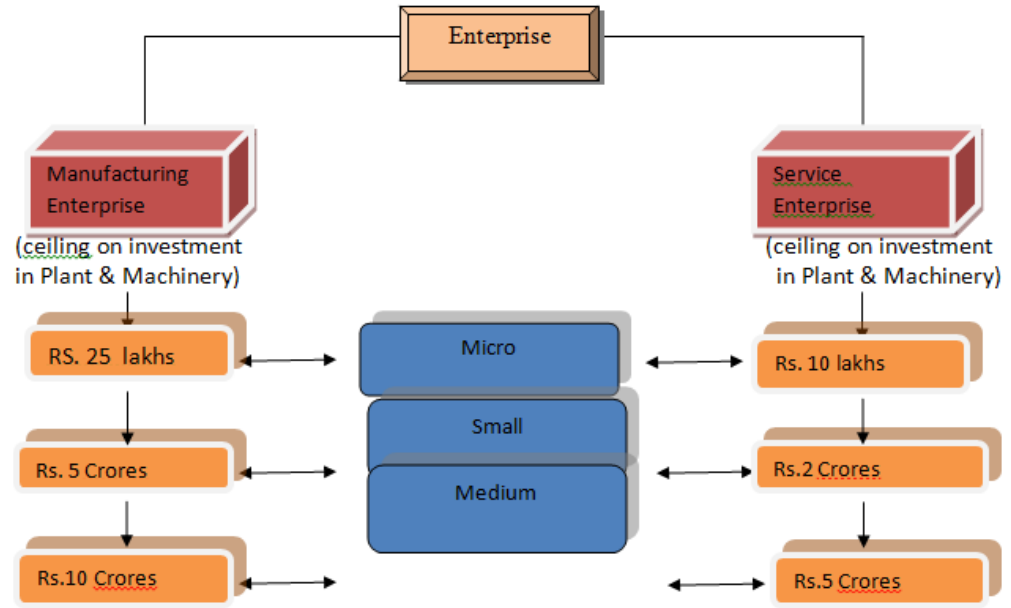

With systematic economic liberalization being implemented, India is a potential candidate to reap the benefits of globalization. The programs and schemes undertaken by the federal ministry promote small scale industries by ensuring the following steps:

. adequate credit from financial institutions/banks

. funds for technology upgrading and modernization

. integrated infrastructural facilities

. modern testing facilities and quality certification laboratories

.access to modern management practices, entrepreneurship development and skill upgrading through appropriate training facilities

. assistance for better access to domestic and export markets

. cluster-wide measures to promote capacity-building and empowerment of the units.

\section{Needs and Strategies}

As globalisation creates benefits through advanced technologies and expansion of commerce, it also creates challenges for emerging small business enterprises to effectively complete in an environment characterised by multivariate challenges.

Entrepreneurship is the practice of starting new organisations or revitalising mature organisations, particularly new businesses generally in response to identified opportunities. Entrepreneurship forces creative destruction across markets and industries, simultaneously creating new products and business models. Many "high value" entrepreneurial ventures seek venture capital or angle funding in order to raise capital to build the business.

Credit assistance to SMEs in India is included along with other national priorities. Such funding assistances to priority sector consist of the credit facilities accorded to

(i) agriculture,

(ii) small scale industry including loans for setting up of industrial estates,

(iii) small road and water transport operators,

(iv) small business,

(v) professional and self employed persons,

(vi) retail trade,

(vii) state sponsored organizations for certain castes and tribes, 
(viii) education,

(ix) housing,

(x) consumption loans granted under the consumption credit scheme and

(xi) liquidity support provided to Regional Rural Banks (RRBs).

Policy guidelines from the government suggest that direct finance to small scale industries (SSI) shall include all loans given to SSI units which are engaged in manufacture, processing or preservation of goods and indirect finance shall include finance to any person providing inputs to or marketing the output of artisans, village and cottage industries, handlooms and to cooperatives of producers in this sector. The credit market structure in India has evolved over the years. A wide range of financial institutions exist in the country to provide credit to various sectors of the economy. These include (not counting the branches or affiliates) 183 commercial banks, 133 regional rural banks (RRBs), numerous financial institutions, 13,014 non-banking financial companies, and 1,853 urban cooperative banks. In addition to these sources of credit, short-term rural credit at the grass root level is emphasized through 31 state co-operative banks, 367 district central co-operative banks (DCCBs), 108,779 primary agricultural cooperatives. State cooperative and agricultural rural development banks (20) and primary cooperative and agricultural rural development banks (727) serve longterm credit needs in rural India.

\section{Role of Entrepreneur in Economic Development}

The industrial health of society depends on the level of entrepreneurship existing in it. Entrepreneurship is basically concerned with creating wealth through production as goods and services. This results in a process of upward change whereby the real per capita income of a country overtime or in other words economic development takes place. Thus entrepreneurial development is the key to economic development.

In fact it is one of the most critical inputs in the economic development of a region. It speeds up the process of activating factors of production leading to a higher rate of economic growth, dispersal of economic activities and development of backward regions. If a region is unable to throw up a sufficient number of entrepreneurs then alien entrepreneurs usually step in to provide goods and services needed by the people. Entrepreneurship begets and also injects entrepreneurship by starting a chain reaction when entrepreneur continuously tries to improve the quality of existing goods and services and add new ones.

While most countries place most entrepreneurial firms in the category of small and medium-sized enterprises (SMEs), India refers to such firms as „Micro, Small and Medium Enterprises. (MSME). After a longstanding demand from various entrepreneurs, small industry associations and related stakeholders for a single comprehensive legislation, the "Micro, Small and Medium Enterprises Development (MSMED) Act, 2006" was enacted. This is the first Act that provides for a precise definition of these enterprises besides paving way for a statutory National Board exclusively for them. This act also helps implement promotion schemes and addresses the development and enhancement of the firms competitiveness. With systematic economic liberalization being implemented, India is a potential candidate to reap the benefits of globalization. The programs and schemes undertaken by the federal ministry promote small scale industries by ensuring the following steps:

. adequate credit from financial institutions/banks

. funds for technology upgrading and modernization

. integrated infrastructural facilities

. modern testing facilities and quality certification laboratories

- access to modern management practices, entrepreneurship development and skill upgrading through appropriate training facilities

. assistance for better access to domestic and export markets

. cluster-wide measures to promote capacity-building and empowerment of the units.

\section{Entrepreneurship Promotional Activities}

India's approach to the promotion of entrepreneurial firms is unique, superfluous, and to some extent, overwhelming. The country has a dedicated ministry for small scale industries at the federal level supported by two agencies; namely, the Small Industry Development Organization (SIDO) and the National Small Industries Corporation Ltd (NSIC). Its role is to suggest policies and programs to address the wide range of issues affecting the productive potential of the large segment of the unorganized micro and small productive units. The role of the Ministry of Small Scale Industries is thus to mainly assist the states in their efforts to promote growth and development of the small scale sector, enhance its competitiveness in an increasingly market-led economy and generating additional employment opportunities.

Small and medium enterprises (SMEs) contribute 7 percent to gross domestic product (GDP), constitute 34 percent of national exports, and account for 40 percent in the manufacturing sector. These units play an 
important role in their direct employment of more than 30 million people. These units in India are usually referred to as small-scale industries (SSI) and are always considered a major segment in the nation priority sector together with agriculture for financial credit from all banking institutions. Presently, the dynamics of business is undergoing a major transformation in the wake of globalization. The liberalization efforts pursued by India have opened new doors of opportunity and, at the same time, have also posed a new set of challenges in a knowledge-based economy. Therefore, a knowledge assessment must include not only economic parameters, but also other important aspects, such as education, health, emancipation of women, and an improvement in overall standard of living. .

Entrepreneurship in China and India has woken up and "the results could reshape business, politics, and society worldwide". The pace of entrepreneurs in both societies is so fast that their rules and laws can hardly keep up. This benefits the spirit of entrepreneurship as doing things in new ways, ahead of social norms and customs, and establishing the rules and laws. Emerging markets and emerging technologies present both challenges and opportunities for businesses and individual entrepreneurs in focusing on competitive advantages for their firms.

\section{CHALLENGES AND OPPORTUNITIES}

The major problems faced by the SSI Sector relate to availability of loan without collateral, delay in getting the loan, high cost of funds, delayed payments, marketing problems, WTO related issues, and sickness. About $10 \%$ of the small scale units are identified as sick and when the sickness prolongs, it leads to the closure of units and unemployment. This trend has wider implications, including funding assistance from the lending institutions turning non-performing assets. It also leads to a loss of scarce material resources and loss of existing employment. Manufacturing goods in India will benefit the SME sector completely. Continued diversification of export basket, improvement of export quality and productivity, increased technology intensity in production, enhanced R\&D activity, reduction of cumbersome regulatory environment, adding flexibility to the existing labour laws, and removal of infrastructural bottlenecks are certain to make the SMEs more innovative and participating.

\section{Conclusion}

India's approach to economic development remains cautious in inward foreign direct investment. Entrepreneurship in general and sophisticated businesses, such as software, biotechnology, and advertising, in particular, has registered significant progress. The country should focus on the creation of congenial environment for success and ensure that entrepreneurs have access to skills, capital and opportunities for networking and exchange to assist its new class of entrepreneurs. Despite its reform experience being very young, "India has made its mark in the global entrepreneurial scene. Indian citizen made their name known as world class entrepreneurs". New opportunities that arise within the country every day create the need for jobs and also an insatiable appetite for new entrepreneurial talent. The priority must be to unite the diverse units of the SMEs under an organized structure and integrate their operations into that of major global firms. The availability of three national-level Entrepreneurship Development Institutes engaged in skill development is a good step to keep the innovative spirit alive and modern. The institutional response may appear overwhelming and superfluous, but this is the best that the government can and must do until the capital and money markets grow sufficiently to address funding needs of the SMEs.

The future prosperity of any economy depends to a considerable extent on its success in promoting entrepreneurship, innovation and the effective and prompt absorption of technological advances developed abroad. In all of these processes, small firms and in particular, those recently established, play a critical role in the development and growth of an economy.

[1]. www.regeringen.se/..d614cc47.pdf

\section{References:}

[2]. Bala Subrahmanya, M.H., "Development Strategies for Indian SMEs: Promoting Linkages with Global Transnational Corporations", Management Research News, September 2007, Vol. 30, Issue 10, pp. 762-774

[3]. http://www. Ncsb2006.se/pdf/ Enterpreneuship.pdf

[4]. The HINDU survey of Indian Industry 2012 